\title{
Research on the Undergraduates Entrepreneurial Education Models Based on Experimental Entrepreneurship Class
}

\author{
(SUBMITTED BUT NOT PRESENTED) \\ ZHANG Liangping \\ Chongqing Technology and Business University, Chongqing, China \\ 313554119@qq.com
}

\begin{abstract}
Analyze the deficiencies of the current entrepreneurship education; Based on the empirical research on entrepreneurship education class in Chongqing Technology and Business University, reforms of entrepreneurship educational models of experimental class, such as teaching design and operational management are explored. Analyze the significance of entrepreneurship experimental class: It can satisfy the customized training needs if high-end students., can effectively build the teaching group of high quality and can serve as a kind of role model for entrepreneurship education.
\end{abstract}

Keywords -entrepreneurship education ; undergraduates ; experimental class ; teaching models

In the last few years, in order to realize the rapid development of Chinese economy by transforming the manufacturing power into the creative one, our government paid great attention to entrepreneurship education, and carried out the top-down widespread promotion and adequate institutional design. The Ministry of Education also declared in Opinions on Vigorously Promoting Innovative Entrepreneurship Education of University and Self-employed Undertaking of Undergraduates. It indicated that the innovation and entrepreneurship education vigorously encourage entrepreneurship in universities. It demonstrated a great strategic move that the educational system is studying thorough practical scientific development concept and serve the innovative country construction. It showed the important way that can deepen education reform of universities as well as cultivate students' innovation and practical ability. It exhibited the crucial measure that can promote the employment of college graduates with business entrepreneurship driving employment.

\section{PROBLEMS EXISTING IN UNDERGRADUATES ENTREPRENEURSHIP EDUCATION IN CHINA.}

Each university carries out widespread practice and exploration to entrepreneurship education model focusing on building the all standing, hierarchical and systematic innovative entrepreneurship educational system of university. It seems that entrepreneurship education are dynamic and vigorous, but the educational achievements are not that good. The problems can be outlined as follows:

\section{A. How to achieve teaching goal}

According to the institutional setting in china, ordinary universities have to bring entrepreneurship courses into Public and Elementary Courses. At present, the teaching goal of entrepreneurship courses is universally defined as creating an atmosphere for entrepreneurship , stimulating the passion for entrepreneurship and enhancing the ability for entrepreneurship However, how to realize such comprehensive and practical goal in specific teaching hasn't be solved. Especially some universities which only focusing on theory teaching have difficulties in specific implementing teaching for such practical and comprehensive courses.

\section{B. How to realize individualized teaching}

Entrepreneurship is a macroscopical proposition which has different meaning in different context. There are a great number of types of entrepreneurship activities, for instance, the scholars like Christy divided the entrepreneurship into reproduction, imitation, home and venture according to influence degree of entrepreneurship on the market and individuals. Because of the students referring to different entrepreneurship types, it can not be easy to materialize the individualized quality teaching. The resources are very limited. Besides, students are different from each other and the conditions of entrepreneurship are diversified. As a result entrepreneurship education is facing the challenge to teach students in accordance with their aptitude.

\section{How to increase the number of teachers and practice}

Apparently, to encourage people to do business creatively and drive innovation, comes along with the tension of shortage in entrepreneurship education resources. The high pressure in teaching also leads to this kind of shortage. Then a weird teaching phenomenon emerges, that is without a experienced teacher, the students who have no passion for entrepreneurship at all, are learned from the entrepreneurship book. The shortage in experienced teachers has become one of the bottleneck to limit the education effect.

\section{BRIEF INTRODUCTION TO “EXPERIMENTAL ENTREPRENEURSHIP CLASS" OF CTBU}

In recent year,CTBU has explored much in entrepreneurial 
education, such as entrepreneurship management course, core general-knowledge course, careers guidance course, general optional course, and experimental entrepreneurship class. It makes great achievement in cultivating students.

In 2014, CTBU started the first session of "College Students Business Simulation and Small Entrepreneur Cultivating Class"(hereinafter referred to as "experimental entrepreneurship class"). The class follows the idea of "at home and abroad, university and enterprise, profession, comprehensiveness" to improve students' creative quality, ability and potential. It sets up the teaching team elaborately and explore the teaching method of simulation entrepreneurship. It has a discussion about entrepreneurship excavation, establishment of small business, entrepreneurship plan, entrepreneurship finance, as well as organizes the teaching. The class also engages the creative entrepreneurship experts from abroad, participating the exploration and teaching all the way. The experimental class doesn't emphasizes the theory or complete process, while it designs the course in accordance with students specific circumstances, especially in their key weakness. For example, we implant a P2P financing platform from Chongqing in the course, to explore how the internet financing can help students to start business. We hope to create an environment by using minority to bring along the majority, enlightening students' passion for entrepreneurship and promoting their abilities to start business.

According to the current process in selecting students and designing teaching model, this model is more valued by the students than the traditional course and entrepreneurship competition.

\section{ANALYSIS OF TALENTS CULTIVATION METHOD OF "EXPERIMENTAL ENTREPRENEURSHIP CLASS"}

The class integrates "knowledge, quality and ability", follows the guideline of entrepreneurship competency training, builds the teaching items supermarket as platform, guided by "Focus on refinement and practice". All this are implemented around unlocking students' potential. In terms of the specific training standard, it particularly absorbs the generalized conception of "entrepreneurship and innovation education" raised in the Tokyo International Entrepreneurship and Innovation Education Conference in 1991. That is: to cultivate most creative people, including initiatives, spirit of adventure, entrepreneurship ability, capacity of working on his own and to develop skills in technology, social and management skills.

Besides these basic tasks, the experimental class also focuses on the exploration of the model of entrepreneurship education, and operation management. The details are as follows:

\section{A. Course teaching reform}

The education concept need to be translated into practice. It needs a platform for the course. Course system is the key to innovation and entrepreneurship education. The system consists of three levels:

1) Facing to all students. It aims to cultivate students' innovation and entrepreneurship consciousness and motivate their willingness.

2) Facing to students with more willingness and potential in innovation and entrepreneurship. It aims to improve students' basic knowledge, skills.

3 ) It aims to cultivate students' abilities in kinds of practice courses, following the guideline of program and activity. It combines teaching and practice and makes pointed references to strengthen the guide to students in the whole process.

The experimental class on the platform of "item supermarket" of CTBU Economic and Management Teaching Center, builds curriculum module according to individuals. It chooses module flexibly, which joints the course and credit, promoting entrepreneurship ability. To be specific, the experimental class sticks to "four unification" in teaching design:

1) Course system. we should unity the item supermarket, quality-oriented education and innovation and entrepreneurship education. It can build comprehensive and modular teaching contents and credit system. It highlights the practical and pertinence.

2 ) Teaching method. We should combine the teachers' teaching with students' own practice, making an equal and interactive teaching method. The subjectivity of teachers and students should be highlight.

3 ) Teaching space. We should active the course teaching and grasp the organic unity of education both in class and out of class. We should build a generative mechanism for teachers and students to cooperate in these kinds of learning and highlight the co-movement of the class. We should focus on the exploration of on-line and off-line teaching model like MOOC, short-video classes.

4) Academic evaluation. We should follow the guideline of "emphasis on process and practice", build a multiagent and multiform evaluation system, to connect study with entrepreneurship, practical training and practice in particular.

\section{B. The reform of operation management}

1) Small class management: the experimental class shall choose the students from the whole students in CTBU with the experience in starting business and being eager to start a business. The number of students should be around 20, which can ensure that the students won't be too much and the students are more excellent. The main teaching method is to discuss, making use of cases and practice.

2) Award completion certificate. As long as the students can finish 5 teaching items(30 periods in total ), achieving the teaching goal, they will awarded the certification as "innovation and entrepreneur experimental class " from national experimental teaching CTBU business \& economic experiment teaching center.

3) Bi-tutor mechanism: the students will be taught by "bitutor mechanism", which means they will have a teacher to teach them practical training, the other teach them practice. The 
match of students and tutors with be decided by two-way selection. Meanwhile, if the students have any international programs, we will introduce the foreign experts to give guidance.

4) Specialized training: according to students' orientation and interest, we will give them particular guidance and specialized training. The core members in the teaching team are teachers with high professional rank, high academic qualifications and experienced in entrepreneur practice. They can give precious suggestions to the students according to specific circumstance and individuals.

\section{ANALYSIS OF SIGNIFICANCE}

We aim to improve college students' innovation and entrepreneur ability, form a good innovation and entrepreneur education environment, build a complete cultivate system to make it recycle positively like a ecosystem. This system should be three-dimensional and in an all-round way. For entrepreneur education, to teach in an experimental class is a good model. It's worth being learned by other teaching model.

\section{A. To meet high-end students' specific needs}

For many years, the entrepreneur education in China is only extended to few crowds. It aims to train the members with entrepreneur desire and experience in starting business. As the trend-encourage people to do business creatively and drive innovation-entrepreneur course has been a required course in college. But there's still a big gap between the theory and practice. As a result, it's necessary to build a new model. This new model will continue the previous high-end training and design the content of courses for the specific crowd which can teach the students in accordance with their capacities.

\section{B. To build superior teaching team}

To implement the innovation education and cultivate innovative talents, we must build a superior teaching team with forward thinking and innovation abilities. The teachers should meet the requirements as follows:

1) To have forward thinking and consciousness of innovation as well as innovation abilities. They can deal with new education information and make effective output.

2 ) To free their mind, renew ideas, dare to try new education model that benefits the students. They can design new education methods and skills as well as skillfully use modern teaching technique, exploring new education and science research areas.

3) To have open character and be tolerant. They should inspire their students and stimulate creative inspiration skillfully.

The number of experimental entrepreneur classes is limited. We can select the teachers at leisure. We can provide more chances to train the teachers which is a good way to improve the quality of the teaching team. At the same time, we can be the model and reference for other experimental entrepreneur classes.

\section{To play the part of demonstration role for entrepreneur education}

On August, 1,2012, General Office of Ministry of Education issued the notification The Basic Requirements(Trial) for General Undergraduate College To Carry Out Entrepreneur Education. As is indicated in the file, carrying out entrepreneur education in general undergraduate college is a strategic move that is under the guideline of accelerating transforming economic developing model and building an innovationoriginated nation rich in human resources. It's an important channel to deepen the reform of higher education, improve the quality of talents, promote students' development in an allround way. It's a crucial measure to drive employment by implementing entrepreneurship which is conductive to realize full employment among college graduates. According to this file, entrepreneurship education should become the general courses in universities. Some universities haven't explore this course, instead, they open the course in a large scale. The quality of education is questionable. In such universities, it's necessary to centralize teaching resources and explore successful entrepreneurship education model as well as expand the course.

\section{CONCLUSION}

Entrepreneur experimental class represents a education model that deserves more discussion. It's also a reasonable supplement for popular personnel cultivating program to cultivate creative talents in starting business. The establishment of experimental class is an effective way to improve students' comprehensive quality, especially in innovation ability, business marketing and management. It helps to cultivate professional skills as well as improve students' employment competitiveness and quality. It's a creative way to explore talents with university-enterprise cooperation.

\section{REFERENCES}

[1] Liu shuqing, Fang xiaodong-Innovation and entrepreneurship education under the implementation of the creative experimental class[J] Heilongjiang Science and Technology Information, 2012(11)

[2] Li wenda-The professional practice and exploration based on experimental innovation and entrepreneurship education classes[J]. Theory and practice of Heilongjiang Education,2014(5)

[3] Li peibin-College students' entrepreneurship education mode innovation of exploration and research_ take entrepreneurship class in Pingdingshan College as an example[J] Journal of Chifeng Institute(JCR Science Edition),2013(7)

[4] Xu xiaozhou-The notion of entrepreneurship education change and strategic choice[J] Zhang min.Educational Research,2012(5)

[5] Michael Shattock.Entrepreneurialism in universities and the knowledge economy:diversification and organizational Change in European Higher Education. . 2009

[6] Per blenker.Entrepreneur Education-lhe new challenges facing the universities. http://pure.au.dk/portal/files/32345606/2006-02_ENG.pdf . 2006

[7] Wang,gang.CDIO engineering education model of reading and thinking. China Higher Education Research . 2009 